\title{
Blueberry necrotic ring blotch virus in Southern Highbush Blueberry: Insights into In Planta and In-Field Movement
}

Tanisha S. Robinson, Harald Scherm, Phillip M. Brannen, Renee Allen, and C. Michael Deom, Department of Plant Pathology, University of Georgia, Athens 30602

\begin{abstract}
Robinson, T. S., Scherm, H., Brannen, P. M., Allen, R., and Deom, C. M. 2016. Blueberry necrotic ring blotch virus in southern highbush blueberry: insights into in planta and in-field movement. Plant Dis. 100:1575-1579.

Blueberry necrotic ring blotch virus (BNRBV) causes an emerging disease of southern highbush blueberry (SHB) in the southeastern United States. Disease incidence and severity vary considerably from year to year within the same planting. Experiments were conducted to determine how the virus spreads in the field. Leaf tissue from symptomatic field plants tested positive for BNRBV in 2011, whereas the same plants were asymptomatic in 2012 and tested negative for the virus. Symptomatic and asymptomatic leaves from individual shoots were tested for the presence of the virus, and symptomatic leaves tested positive (100\%), whereas $65.4 \%$ of the asymptomatic leaves from the same shoots tested negative. Leaves were selected in which half the leaf blade was symptomatic and the other half was not; symptomatic leaf halves tested positive $(100 \%)$, whereas $76.0 \%$ of the asymptomatic halves from the same leaf tested

negative for the virus. When virus-free, potted trap plants were interspersed in the field among established plants that had shown disease symptoms the previous year, disease onset in trap plants was observed 2 to 3 weeks after disease onset in field plants. In a separate experiment, asymptomatic softwood cuttings were collected from mother plants symptomatic for BNRBV, rooted, and monitored for symptom development for a period of 12 to 27 months. No BNRBV symptoms were observed in the progeny, whereas disease incidence was high for cuttings taken at the same time from plants infected with Blueberry red ringspot virus used as a control. Collectively, these studies suggest that BNRBV does not infect SHB plants systemically and is not transmitted through vegetative propagation, and that the virus likely does not persist in plants after natural defoliation in the fall.
\end{abstract}

Blueberry is Georgia's most important fruit crop in both acreage and economic value, producing over $\$ 312$ million in farm gate value in 2013 (Wolfe and Stubbs 2014). Rabbiteye blueberry (Vaccinium virgatum) presently accounts for approximately $70 \%$ of production, with southern highbush blueberry (SHB; V. corymbosum interspecific hybrids) accounting for the remainder (P. M. Brannen, personal communication). Despite their smaller acreage, SHB cultivars are economically very important because their fruit matures during an early and economically favorable market window (late April to mid-May in Georgia).

In 2006, a new disease of SHB, blueberry necrotic ring blotch disease (BNRBD), was first observed in Georgia and subsequently reported in several southeastern states, including North and South Carolina, Florida, and Mississippi (Martin et al. 2012). Many SHB cultivars are susceptible to the disease (Scherm et al. 2008). Symptoms appear as irregularly shaped, reddish-brown to black rings or blotches with or without green centers on both leaf surfaces. Eventually, the spots may coalesce to cover the entire leaf. Symptoms are generally more prevalent on older leaves in the lower portion of the canopy. In severe cases, the disease may lead to premature defoliation (P. M. Brannen, personal communication). To date, disease symptoms have not been observed in rabbiteye cultivars.

Blueberry necrotic ring blotch virus (BNRBV), a novel virus in the proposed new genus Blunervirus, is associated with BNRBD. BNRBV possesses a 14-kb nucleotide genome divided into four singlesided RNA segments, and sequence analysis suggests that BNRBV likely evolved from recombination events between species of Ilavirus (family

Current address of T. S. Robinson: Ball Horticultural Company, 622 Town Road, West Chicago, IL 60185.

Corresponding author: C. M. Deom; E-mail: deom@uga.edu

Accepted for publication 9 March 2016.

http://dx.doi.org/10.1094/PDIS-09-15-1035-RE

(C) 2016 The American Phytopathological Society
Bromoviridae) and Tobamovirus (family Virgaviridae) (Quito-Avila et al. 2013). In addition, phylogenetic analysis indicated that the closest relatives of BNRBV are Citrus leprosis virus (CiLV) and Hibiscus green spot virus (HGSV) (Quito-Avila et al. 2013), both members of the family Virgaviridae. CiLV and HGSV are transmitted by Brevipalpus phoenicis (false spider mite), which migrate over short distances in the field. CiLV moves locally from cell to cell but does not move systemically in infected plants (Rodrigues et al. 2003). For BNRBV, the large variation in disease intensity observed from year to year in infected blueberry plantings also suggests limited systemic movement, but the degree to which the virus moves locally versus systemically in infected plants has not been determined. There is currently no information available on the epidemiology of BNRBV, including its means of spread or transmission.

To gain insights into BNRBV movement in planta, we determined the ability of BNRBV to persist in infected SHB plants from one year to the next, established whether onset of disease symptoms on fieldexposed trap plants correlates with the onset of symptoms in field plants, and monitored the levels of transmission of the virus through vegetative propagation via asymptomatic cuttings taken from symptomatic mother plants over a period of 12 to 27 months.

\section{Materials and Methods}

Persistence of BNRBV in affected plantings from year to year. The study was conducted in two commercial blueberry plantings near Enigma (Berrien County) and Homerville (Clinch County), GA with a history of BNRBD. When these field sites were surveyed in summer 2011, disease incidence was high, and most plants showed severe foliar symptoms. Fifteen symptomatic plants of 'Star' SHB were selected and marked at each site, and one symptomatic shoot was collected from each plant for virus confirmation from Homerville on 25 June and Enigma on 9 July 2011. Star was used for this study because it is highly susceptible to BNRBD and the most common SHB cultivar grown in Georgia. Six leaves per shoot were individually analyzed by reverse transcription-polymerase chain reaction (RT-PCR), as described below, to confirm the presence of BNRBV. The incidence and severity of disease symptoms, based on visual assessment, were much less in the two test plantings in 2012 (30.0 and 
$1.0 \%$ of the plants in the fields at Enigma and Homerville, respectively). The same 15 plants per planting were sampled again in June 2012 using the same sampling strategy (one shoot per plant, six leaves per shoot) as in 2011 , with the only difference being that plants were asymptomatic in 2012.

Testing asymptomatic and symptomatic leaves from the same shoot for BNRBV. Individual current-season shoots from 11 symptomatic Star plants (one shoot per plant) showing symptoms of BNRBD were sampled in fall 2012 at the Enigma site. All shoots used had emerged following routine hedging of the plants during early summer. The shoots displayed mixed symptoms (i.e., asymptomatic leaves and leaves with moderate to severe symptoms distributed along the shoot). Three to four leaves were arbitrarily taken from the top (apical), middle, and bottom of each shoot for a total of 39 samples, and analyzed by RT-PCR for BNRBV as described below. RNA from uninfected leaf tissue maintained in the greenhouse was used as a negative control.

For half-leaf analysis, 13 leaves were collected from individual plants showing symptoms of BNRBD at the test sites in Homerville and Enigma in June 2012. Leaves chosen displayed symptoms of moderate to severe disease symptoms on one half of the leaf, whereas the other half was asymptomatic. Virus detection was by RT-PCR, as described below, for each half leaf.

Disease transmission to potted trap plants in the field. Potted virus-free trap plants were used to determine how rapidly symptoms appear on newly introduced plants when placed into a planting with a history of BNRBD. Tissue-cultured plugs of cultivar Star were placed in $15-\mathrm{cm}$ plastic containers in a potting mix containing pine bark and sand at a 3:1 ( $\mathrm{vol} / \mathrm{vol})$ ratio and raised in a greenhouse at 22 to $24^{\circ} \mathrm{C}$ with $13 \mathrm{~h}$ of light. Plants were fertilized with Miller Nutri-Leaf soluble liquid fertilizer (20:20:20 NPK) for 1 month, and Scott's Osmocote was applied at 3- to 4-month intervals; plants were watered as needed. Two and a half months after transplanting, trap plants (13 per field site) were placed into two commercial blueberry plantings near Enigma and Willacoochee (Atkinson County), GA in March 2012. Trap plant height was variable but most plants were, on average, approximately $40 \mathrm{~cm}$ tall when exposed and had multiple shoots. Each of the two field sites where trap plants were exposed consisted of mature plants of Star and had a history of BNRBD, but no visual disease symptoms were present at the time of trap plant exposure. Symptom development was monitored on the foliage of both trap plants and field plants at biweekly intervals until symptoms developed on both (June). Control plants not exposed to natural field conditions were maintained in the greenhouse and were also monitored for symptom development. All test plants were assayed via RT-PCR for BNRBV before and after exposure to natural field conditions. All trap plants were negative for BNRBV before exposure to field conditions.

RNA extraction and RT-PCR. Leaves were washed with absolute ethanol for $1.5 \mathrm{~min}$ and dried prior to RNA extraction. Total RNA was extracted from $100 \mathrm{mg}$ of fresh leaf tissue using the RNeasy Plant Mini Kit (Qiagen, Valencia, CA). RNA extracted from leaf tissue of uninfected plants maintained in the greenhouse was used as a negative control.

RNA was subjected to RT-PCR with virus-specific primers (forward) 5'-CCAGTTTGGAGGAATTGCAT 3'and (reverse) 5'-GCGTT TCAGCACCACTAAC- $3^{\prime}$ as originally described by Quito-Avila et al. (2013) and modified and optimized by Cantu-Iris et al. (2013). RT-PCR was performed with the OneStep RT-PCR kit (Qiagen) according to the manufacturer's instructions. The PCR volume was $25 \mu \mathrm{l}$, which included $13 \mu l$ of RNase-free water, $5 \mu l$ of $5 \times$ OneStep RT-PCR buffer, $1 \mu \mathrm{l}$ of $10 \mathrm{mM}$ dNTP mix, $1.5 \mu \mathrm{l}$ of $0.6 \mu \mathrm{M}$ forward primer, $1.5 \mu \mathrm{l}$ of $0.6 \mu \mathrm{M}$ reverse primer, $2 \mu \mathrm{l}$ of template RNA, and $1 \mu \mathrm{l}$ of OneStep RT-PCR enzyme mix. The following thermal profile was used: 40 cycles of $30 \mathrm{~s}$ at $94^{\circ} \mathrm{C}, 20 \mathrm{~s}$ at $55^{\circ} \mathrm{C}$, and $45 \mathrm{~s}$ at $72^{\circ} \mathrm{C}$, preceded by an initial denaturation for $1 \mathrm{~min}$ at $95^{\circ} \mathrm{C}$ and followed by a 10-min extension at $72^{\circ} \mathrm{C}$. The expected cDNA amplicon was $432 \mathrm{bp}$ and was visualized on a $1 \%$ agarose gel.

Transmission of BNRBV via softwood cuttings. Softwood cuttings were taken in commercial plantings of mature Star plants in June (spring cuttings) and September (fall cuttings) 2010 and 2011.
The fields selected were of similar age but differed in the types of disease present, as determined by visual assessment or prior RT-PCR testing: (i) asymptomatic plants, (ii) plants with BNRBV symptoms, and (iii) plants with Blueberry red ringspot virus (BRRV) symptoms. The latter virus was used as a positive control because it is known to move systemically in blueberry and is readily transmitted by vegetative propagation (Martin et al. 2012). Cuttings were 15 to $20 \mathrm{~cm}$ in length, and only asymptomatic cuttings (i.e., sections not showing visual symptoms) were collected from the symptomatic mother plants. Approximately 300 cuttings were collected from each field. A sterile scalpel was used to make a $2-\mathrm{cm}$ vertical incision at the base of each cutting from the fall collections to facilitate rooting; there was no such wounding needed for the spring cuttings. The bases of the cuttings were subsequently dipped into potassium-indole-acetic acid plant growth hormone at 2,500 ppm before placing into 36-well trays containing milled pine bark. Four trays (replicates) were prepared for each of the three disease treatments. The trays were arranged in a randomized complete block design on a mist bench in a greenhouse for rooting. Greenhouse conditions were 21 to $31^{\circ} \mathrm{C}$ for spring cuttings with $14 \mathrm{~h}$ of daylight and 11 to $26^{\circ} \mathrm{C}$ for fall cuttings with $12 \mathrm{~h}$ of daylight.

At 8 to 10 weeks following the initiation of rooting, 10 cuttings from asymptomatic and BRRV-symptomatic mother plants as well as 20 cuttings from BNRBV-symptomatic mother plants per replicate were transplanted into 2.8-liter pots containing fine pine bark/sand (3:1) and 14-14-14 NPK fertilizer; these cuttings were subsequently raised in a greenhouse at 21 to $29^{\circ} \mathrm{C}$, watered daily, and fertilized monthly with a 20-20-20 NPK liquid fertilizer.

A visual disease assessment was done 3 months after transplanting for each trial. After overwintering in the greenhouse, plants were transplanted to larger 5.6- or 8.4-liter pots and moved to an insectproof screenhouse (51-by-25 mesh) in the spring (April) and monitored monthly for symptom development during the season. Any leaves with symptoms potentially resembling BNRBV were sampled and frozen for RT-PCR analysis. No molecular confirmation was done for BRRV because previous work documented an excellent relationship between the presence of BRRV visual symptoms and PCR detection (Polashock et al. 2009).

\section{Results}

Persistence of BNRBV in affected plantings from year to year. Previous field observations indicated considerable variability in disease symptoms in blueberry plantings affected by BNRBV from year to year, whereby plants showing symptoms one year were asymptomatic the following year. In the 2011 growing season, 92.0 and $72.0 \%$ of the plants showed symptoms at Homerville and Enigma, respectively, by the end of June. However, much less disease was observed in 2012, with only 1.0 and $30.0 \%$ of plants showing symptoms by late June at Homerville and Enigma, respectively. To determine whether symptom expression correlates with the detection of BNRBV, asymptomatic plants in 2012 that had been symptomatic and had tested positive for the virus in 2011 were assayed by RTPCR (Table 1). Leaf extracts from all 30 asymptomatic test plants in 2012 tested negative for BNRBV (total of 180 leaves assayed).

Testing asymptomatic and symptomatic leaves from the same shoot for BNRBV. Of the 39 leaves sampled from shoots having both symptomatic and asymptomatic leaves (Fig. 1A), 26 were asymptomatic and the remaining 13 were symptomatic, based on visual assessment. RT-PCR results showed that 17 of the asymptomatic leaves $(65.4 \%)$ tested negative for the virus. The 13 leaves that displayed visual symptoms all tested positive (Table 2).

In total, 13 leaves were sampled that specifically displayed BNRBD symptoms on only one half of the leaf (Fig. 1B), and 10 of the 13 symptomless leaf halves (76.9\%) tested negative for BNRBV by RT-PCR. The symptomatic leaf halves all tested positive for BNRBV (Table 3).

Disease transmission to potted trap plants in the field. Trap plants exposed in two commercial blueberry plantings in mid-March 2012 first showed symptoms of BNRBD on 25 June at Enigma and 9 July at Willacoochee, 14 and 16 weeks after initial exposure, respectively (Table 4). Disease severity was moderate to severe, with 
individual disease severity values determined by visual observation ranging from 45.0 to $70.0 \%$ of the leaf area affected. Symptoms were observed on most leaves of the trap plants, but symptoms on older leaves were more severe than on younger leaves. By comparison, disease was observed 2 to 3 weeks earlier in field plants at the exposure sites, with an incidence of $30.0 \%$ at Enigma on 25 June and $100 \%$ at Willacoochee on 9 July. Surviving trap plants at both sites showed $100 \%$ disease incidence by 30 July. RT-PCR analysis confirmed the presence of BNRBV in all symptomatic trap plants (Table 4). No symptoms were observed on control trap plants maintained in the greenhouse. All control plants tested negative for BNRBV before and after the field exposure period.

Transmission of BNRBV via softwood cuttings. After the 8- to 10 -week rooting period, the cutting from BRRV mother plants consistently showed symptoms typical of the corresponding disease (chlorotic mottling and spotting), with incidence levels ranging from 32.5 to $97.5 \%$ (Table 5). This suggests that BRRV had moved into tissue of the asymptomatic cuttings prior to their removal from the mother plants. This was expected because BRRV has previously been shown to move systemically in infected plants and be transmitted by vegetative propagation (Martin et al. 2012). Symptoms typical of BNRBV were observed very rarely in the rooting trays, with only cuttings in the spring 2011 trial from the BNRBV-symptomatic mother plants becoming symptomatic at an incidence of $4.9 \%$ (Table 5).

After 3 months of growth, visual disease incidence continued to be high for BRRV cuttings, ranging from 37.5 to $97.5 \%$. Only one of the four trials showed visual symptom development for plants from BNRBV cuttings, with a disease incidence of $1.4 \%$. However, when leaf samples from these symptomatic plants were assayed for BNRBV, all RT-PCR tests were negative.

After plants derived from the rooted cuttings had spent their first winter in the greenhouse, they were transplanted into 5.6- or 8.4-liter pots in April and moved to an insect-proof screenhouse outdoors. These plants were then monitored periodically for symptom development. A comprehensive disease assessment on all plants was conducted in September 2012, 27 and 25 months after the 2010 cuttings had been taken and 15 and 12 months after the 2011 cuttings had been collected. Visual disease incidence continued to be high for BRRV cuttings, ranging from 54.3 to $96.8 \%$ across the four trials

Table 1. Detection of Blueberry necrotic ring blotch virus via reversetranscription (RT)-PCR in individual Star southern highbush blueberry plants that were symptomatic in 2011 and asymptomatic in 2012 for blueberry necrotic ring blotch disease at two different sites (Homerville and Enigma) in Georgia

\begin{tabular}{lccccc}
\hline & \multicolumn{5}{c}{ Symptoms/RT-PCR } \\
\cline { 2 - 4 } & \multicolumn{2}{c}{$\mathbf{2 0 1 1}$} & & \multicolumn{2}{c}{ 2012 } \\
\cline { 2 - 4 } \cline { 5 - 6 } Plant $^{\mathbf{b}}$ & Homerville & Enigma & & Homerville & Enigma \\
\hline 1 & $+/+$ & $+/+$ & & $-/-$ & $-/-$ \\
2 & $+/+$ & $+/+$ & & $-/-$ & $-/-$ \\
3 & $+/+$ & $+/+$ & & $-/-$ & $-/-$ \\
4 & $+/+$ & $+/+$ & & $-/-$ & $-/-$ \\
5 & $+/+$ & $+/+$ & & $-/-$ & $-/-$ \\
6 & $+/+$ & $+/+$ & & $-/-$ & $-/-$ \\
7 & $+/+$ & $+/+$ & & $-/-$ & $-/-$ \\
8 & $+/+$ & $+/+$ & & $-/-$ & $-/-$ \\
9 & $+/+$ & $+/+$ & & $-/-$ & $-/-$ \\
10 & $+/+$ & $+/+$ & & $-/-$ & $-/-$ \\
11 & $+/+$ & $+/+$ & & $-/-$ & $-/-$ \\
12 & $+/+$ & $+/+$ & & $-/-$ & $-/-$ \\
13 & $+/+$ & $+/+$ & $-/-$ & $-/-$ \\
14 & $+/+$ & $+/+$ & $-/-$ & $-/-$ \\
15 & $+/+$ & $+/+$ & $-/-$ & $-/-$ \\
\hline
\end{tabular}

a Symbols indicate presence (+) or absence (-) of foliar symptoms of blueberry necrotic ring blotch disease, and positive $(+)$ or negative $(-)$ detection by RT-PCR for BNRBV. Samples were collected in June in both years.

${ }^{b}$ One shoot was sampled from each plant, with six leaves tested per shoot.
(Table 5). No BNRBV plants showed any visual symptoms (Table 5). Overall transmission percentages across all plants in the four trials were $78.6 \%$ for BRRV (based on visual symptoms) and $0 \%$ for BNRBV (based on visual symptoms and RT-PCR).
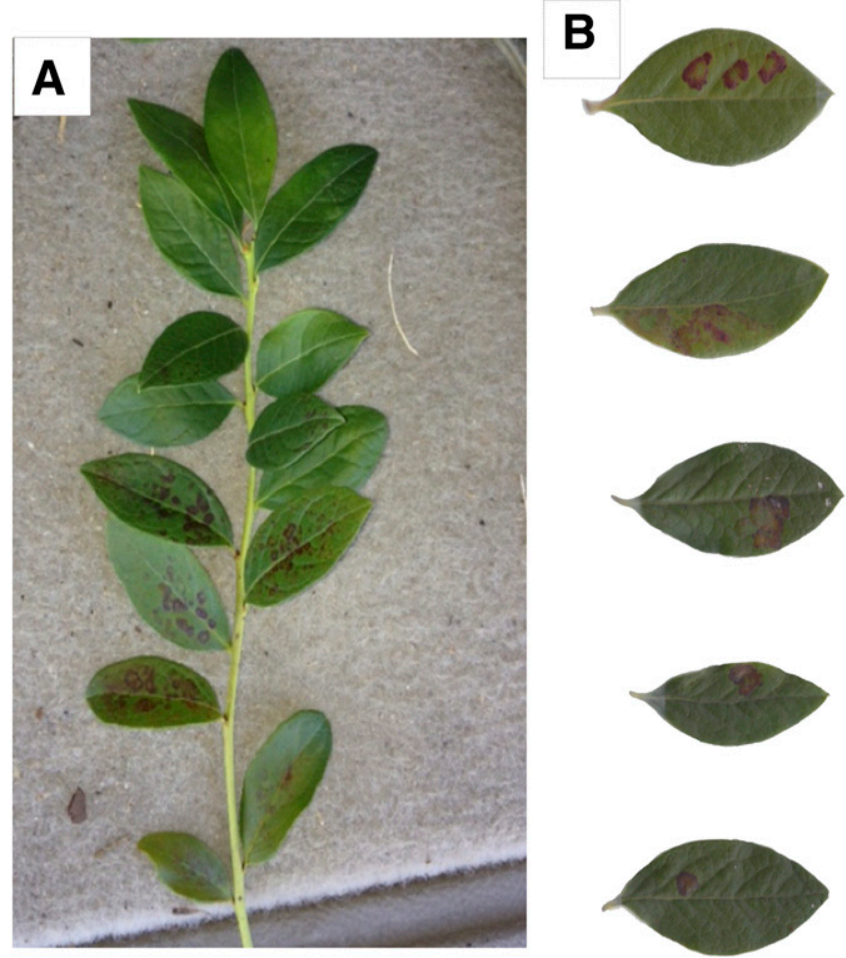

Fig. 1. A, Star southern highbush blueberry shoot displaying leaves with and without symptoms of blueberry necrotic ring blotch disease. B, Leaves of Star southern highbush blueberry in which one half of the leaf was symptomatic and the other half was not. Leaf halves were subsequently tested separately for the presence or absence of Blueberry necrotic ring blotch virus.

Table 2. Detection of Blueberry necrotic ring blotch virus (BNRBV) via reverse-transcription (RT)-PCR in individual leaves of Star southern highbush blueberry shoots displaying mixed symptoms of blueberry necrotic ring blotch disease

\begin{tabular}{|c|c|c|c|c|c|c|c|c|c|c|c|}
\hline \multirow[b]{2}{*}{ Leaf $^{\mathbf{b}}$} & \multicolumn{11}{|c|}{ Visual/PCR for each shoot number ${ }^{a}$} \\
\hline & 1 & 2 & 3 & 4 & 5 & 6 & 7 & 8 & 9 & 10 & 11 \\
\hline 1 & $-1-$ & $-1+$ & $-1+$ & $-/ \mathrm{N}$ & $-1-$ & $-1+$ & $-1-$ & $-1-$ & $-1-$ & $-/+$ & $+/ \mathrm{N}$ \\
\hline 2 & $-/ \mathrm{N}$ & $-/ \mathrm{N}$ & $-/ \mathrm{N}$ & $-1-$ & $-/ \mathrm{N}$ & $-/ \mathrm{N}$ & $-/ \mathrm{N}$ & $-/ \mathrm{N}$ & $-/ \mathrm{N}$ & $-/ \mathrm{N}$ & $-/ \mathrm{N}$ \\
\hline 3 & $-/ \mathrm{N}$ & $-/ \mathrm{N}$ & $-/ \mathrm{N}$ & $-/ \mathrm{N}$ & $-/ \mathrm{N}$ & $-/ \mathrm{N}$ & $-/ \mathrm{N}$ & $-/ \mathrm{N}$ & $-/ \mathrm{N}$ & $-/ \mathrm{N}$ & $-/+$ \\
\hline 4 & $-/ \mathrm{N}$ & $-1+$ & $-/ \mathrm{N}$ & $-/ \mathrm{N}$ & $-1-$ & $-1-$ & $-/ \mathrm{N}$ & $-/ \mathrm{N}$ & $-/ \mathrm{N}$ & $-/ \mathrm{N}$ & $+/ \mathrm{N}$ \\
\hline 5 & $-/ \mathrm{N}$ & $-/ \mathrm{N}$ & $-/ \mathrm{N}$ & $-1+$ & $-/ \mathrm{N}$ & $-/ \mathrm{N}$ & $-/ \mathrm{N}$ & $+/+$ & $-/ \mathrm{N}$ & $-/ \mathrm{N}$ & $+/ \mathrm{N}$ \\
\hline 6 & $-/ \mathrm{N}$ & $+/+$ & $-1-$ & $-/ \mathrm{N}$ & $-/ \mathrm{N}$ & $-/ \mathrm{N}$ & $-/ \mathrm{N}$ & $-/ \mathrm{N}$ & $-/ \mathrm{N}$ & $+/+$ & $+/ \mathrm{N}$ \\
\hline 7 & $-/ \mathrm{N}$ & $-/ \mathrm{N}$ & $+/+$ & $-/ \mathrm{N}$ & $-/ \mathrm{N}$ & $-/ \mathrm{N}$ & $-/ \mathrm{N}$ & $-1-$ & $-/ \mathrm{N}$ & $-/ \mathrm{N}$ & $+/+$ \\
\hline 8 & $-/ \mathrm{N}$ & $-/+$ & $-/ \mathrm{N}$ & $-/ \mathrm{N}$ & $-/ \mathrm{N}$ & $+/+$ & $-/ \mathrm{N}$ & $-/ \mathrm{N}$ & $+/ \mathrm{N}$ & $+/ \mathrm{N}$ & $+/ \mathrm{N}$ \\
\hline 9 & $-/+$ & $-/ \mathrm{N}$ & $-/ \mathrm{N}$ & $-/ \mathrm{N}$ & $+/ \mathrm{N}$ & $-/ \mathrm{N}$ & $-1-$ & $-/ \mathrm{N}$ & $-1-$ & $-/ \mathrm{N}$ & $+/ \mathrm{N}$ \\
\hline 10 & $+/+$ & $-/ \mathrm{N}$ & $-/ \mathrm{N}$ & $+/+$ & $+/+$ & $-/ \mathrm{N}$ & $+/+$ & $-/ \mathrm{N}$ & $-1-$ & $-/ \mathrm{N}$ & $+/+$ \\
\hline 11 & $-/ \mathrm{N}$ & $-/ \mathrm{N}$ & $-/ \mathrm{N}$ & $-1-$ & $-/ \mathrm{N}$ & $+/ \mathrm{N}$ & $-1-$ & $-1-$ & $-/ \mathrm{N}$ & $-1-$ & $+/ \mathrm{N}$ \\
\hline 12 & $-/ \mathrm{N}$ & $\ldots$ & $-/ \mathrm{N}$ & $\ldots$ & $-/ \mathrm{N}$ & $+/ \mathrm{N}$ & $-/ \mathrm{N}$ & $-/ \mathrm{N}$ & $+/+$ & $-/ \mathrm{N}$ & $+/ \mathrm{N}$ \\
\hline 13 & $-/ \mathrm{N}$ & $\ldots$ & $\ldots$ & $\ldots$ & $-/ \mathrm{N}$ & $+/+$ & $\ldots$ & $-/ \mathrm{N}$ & $-/ \mathrm{N}$ & $-/ \mathrm{N}$ & $+/ \mathrm{N}$ \\
\hline 14 & $\ldots$ & $\ldots$ & $\ldots$ & $\ldots$ & $+/ \mathrm{N}$ & $+/ \mathrm{N}$ & $\ldots$ & $-/ \mathrm{N}$ & $-/ \mathrm{N}$ & $-/ \mathrm{N}$ & $+/ \mathrm{N}$ \\
\hline 15 & $\ldots$ & $\ldots$ & $\ldots$ & $\ldots$ & $+/ \mathrm{N}$ & $+/ \mathrm{N}$ & $\ldots$ & $-/ \mathrm{N}$ & $-/ \mathrm{N}$ & $\ldots$ & $\ldots$ \\
\hline 16 & $\ldots$ & $\ldots$ & $\ldots$ & $\ldots$ & $+/ \mathrm{N}$ & $+/ \mathrm{N}$ & $\ldots$ & $-/ \mathrm{N}$ & $-/ \mathrm{N}$ & $\ldots$ & \\
\hline
\end{tabular}

a Symbols indicate visual observation of whether leaf was symptomatic $(+)$ or asymptomatic $(-)$ for blueberry necrotic ring blotch disease and positive $(+)$ or negative (-) detection by RT-PCR for BNRBV. N = leaves not tested.

b Leaf number 1 denotes the tip of the shoot (youngest leaf). 


\section{Discussion}

BNRBV is a novel blueberry virus associated with BNRBD affecting SHB in the southeastern United States (Quito-Avila et al. 2013). In this study, the correlation between visual BNRBD symptoms and the detection of BNRBV was determined in field plants across

Table 3. Detection of Blueberry necrotic ring blotch virus (BNRBV) via reversetranscription polymerase chain reaction (RT-PCR) in individual leaf halves of Star southern highbush blueberry showing symptoms of blueberry necrotic ring blotch disease on one half leaf but not the other

\begin{tabular}{lcc}
\hline & \multicolumn{2}{c}{ Visual/PCR } \\
\cline { 2 - 3 } Leaf & Leaf half 1 & Leaf half 2 \\
\hline 1 & $+/+$ & $-/-$ \\
2 & $-/-$ & $+/+$ \\
3 & $-/-$ & $+/$ \\
4 & $+/+$ & $-/+$ \\
5 & $+/+$ & $-/-$ \\
6 & $+/+$ & $-/-$ \\
7 & $+/+$ & $-/-$ \\
8 & $-/-$ & $+/+$ \\
9 & $-/+$ & $+/+$ \\
10 & $+/+$ & $-/-$ \\
11 & $+/+$ & $-/-$ \\
12 & $-/+$ & $+/+$ \\
13 & $+/+$ & $-/-$ \\
\hline
\end{tabular}

a Symbols indicate visual observation of whether leaf half was symptomatic $(+)$ or asymptomatic (-) for blueberry necrotic ring blotch disease and positive (+) or negative (-) detection by RT-PCR for BNRBV.

Table 4. Symptom onset, visual disease incidence (DI), and reverse-transcription polymerase chain reaction (PCR) confirmation of Blueberry necrotic ring blotch virus (BNRBV) on potted Star trap plants in two commercial blueberry plantings with a history of the disease in 2012

\begin{tabular}{lccccc}
\hline Site & $\begin{array}{c}\text { Date } \\
\text { exposed }^{\mathbf{a}}\end{array}$ & $\begin{array}{c}\text { First } \\
\text { symptoms }^{\mathbf{b}}\end{array}$ & $\begin{array}{c}\text { Trap } \\
\text { plants }\end{array}$ & $\begin{array}{c}\text { DI } \\
(\boldsymbol{\%})\end{array}$ & $\begin{array}{c}\text { Positive } \\
(\boldsymbol{\%})^{\mathbf{c}}\end{array}$ \\
\hline Enigma & 16 March & 25 June & 6 & 100.0 & 100.0 \\
Willacoochee & 16 March & 9 July & 8 & 100.0 & 100.0 \\
\hline
\end{tabular}

a Date when trap plants were exposed to natural field conditions for the first time.

b First date symptoms were observed on trap plants.

${ }^{\mathrm{c}} \mathrm{PCR}$ positive for BNRBV. growing seasons as well as within plants in a single season. In addition, we confirmed the lack of in planta movement of BNRBV through vegetative propagation via asymptomatic softwood cuttings taken from symptomatic mother plants. Results from this study suggest that (i) BNRBV does not persist in SHB plants from one season to another and (ii) the virus causes a localized infection at a putative vector feeding site.

Based on genome similarities to CiLV and HGSV, it has been predicted that BNRBV transmission through vegetative propagation would be minimal (Martin et al. 2012) because of the lack of systemic movement of the CiLV in planta, and this was confirmed for BNRBV in the present study. We noted a few plants with symptoms resembling BNRBD during the propagation process $(1.4 \%$ incidence in one trial) but these plants tested negative for BNRBV by RT-PCR. Although there is generally an excellent relationship between BNRBV symptoms and RT-PCR test results (Martin et al. 2012), it is likely that the symptoms observed on the potted plants in the present study were not due to BNRBV. As such, there is no conclusive experimental evidence to date that BNRBV can be transmitted via vegetative propagation. In contrast, asymptomatic cuttings taken from BRRV-infected mother plants as a control treatment consistently developed symptoms of the corresponding disease during the rooting phase, regardless of whether the cuttings were collected in the spring or fall. This was expected because BRRV is known to move systemically in infected plants and effectively acts as a positive control for phloem-dependent long-distance movement.

The incidence of BNRBD can be highly variable from year to year in affected SHB plantings. We assessed and assayed plants in 2012 that were asymptomatic but had been symptomatic in 2011 . The absence of detectable BNRBV in these plants suggests that the virus does not persist following leaf abscission in the fall, which would indicate that BNRBV does not infect the plants systemically through the vascular system. Therefore, symptoms on individual leaves result from new localized infections likely associated with feeding of a potential vector. It was shown previously that $\mathrm{CiLV}$, which is related to BNRBV (Quito-Avila et al. 2013), does not move systemically in its host but, rather, remains localized or has limited movement over very short distances in the host tissue (Rodrigues et al. 2003). CiLV is vectored on citrus by the false spider mite, B. phoenicis (Rodrigues et al. 2003) (also, experimentally, by B. californicus and B. obovatus; Chung and Brlanksy 2006). Nonvector transmission is only successful when symptomatic tissue areas are in direct contact with receptor tissue on healthy plants (Chung and Brlanksy 2006) and then only in receptor plant tissues at the contact areas, supporting the suggestion that CiLV causes a localized disease. With BNRBV, future research

Table 5. Symptom development and real-time polymerase chain reaction (PCR) confirmation on Star southern highbush blueberry softwood cuttings taken from mother plants that were symptomatic for Blueberry necrotic ring blotch virus (BNRBV) and Blueberry red ringspot virus (BRRV) ${ }^{\mathrm{a}}$

\begin{tabular}{|c|c|c|c|c|}
\hline \multirow[b]{2}{*}{ Trial, treatment } & \multirow{2}{*}{$\frac{\text { Rooting tray (8 to } 10 \text { weeks) }}{\text { VDI (\%) }}$} & \multicolumn{2}{|c|}{ Greenhouse (3 months) } & \multirow{2}{*}{$\frac{\text { Screenhouse (12 to } 27 \text { months) }}{\text { VDI (\%) }}$} \\
\hline & & VDI $(\%)$ & Positive $(\%)^{\mathbf{b}}$ & \\
\hline \multicolumn{5}{|l|}{ Spring 2010} \\
\hline BRRV & 51.3 & 80.5 & $\ldots$ & 73.5 \\
\hline BNRBV & 0 & 0 & $\ldots$ & 0 \\
\hline Asymptomatic & 0 & 0 & $\ldots$ & 0 \\
\hline \multicolumn{5}{|l|}{ Fall 2010} \\
\hline BRRV & 97.5 & 97.5 & $\ldots$ & 74.4 \\
\hline BNRBV & 0 & 0 & $\ldots$ & 0 \\
\hline Asymptomatic & 0 & 0 & $\ldots$ & 0 \\
\hline \multicolumn{5}{|l|}{ Spring 2011} \\
\hline BRRV & 32.5 & 37.5 & $\ldots$ & 54.3 \\
\hline BNRBV & 4.9 & 0 & $\ldots$ & 0 \\
\hline Asymptomatic & 0 & 0 & $\ldots$ & 0 \\
\hline \multicolumn{5}{|l|}{ Fall 2011} \\
\hline BRRV & 78.1 & 66.7 & $\ldots$ & 96.8 \\
\hline BNRBV & 0 & 1.4 & 0 & 0 \\
\hline Asymptomatic & 0 & 0 & $\ldots$ & 0 \\
\hline
\end{tabular}

a All cuttings were asymptomatic when collected in the field. VDI = visual disease incidence.

b PCR positive for BNRBV. 
to identify the vectors and subsequent vector transmission studies in parallel with grafting studies will provide additional evidence that BNRBV only moves locally in SHB. An alternate explanation for the lack of apparent systemic movement of BNRBV is that the virus induces an RNA silencing mechanism. Future experiments are being designed to address this possibility.

Although there was a 1:1 correlation between the detection of the virus and disease symptoms within symptomatic and asymptomatic plants across years, a less definitive correlation existed within individual shoots from infected plants. When asymptomatic and symptomatic leaves were taken from the same shoot, $65.4 \%$ of the asymptomatic leaves tested negative for BNRBV, whereas $34.6 \%$ of the asymptomatic leaves and all of the symptomatic leaves tested positive for the virus. Similarly, $76.9 \%$ of asymptomatic leaf halves tested negative for BNRBV, whereas $23.1 \%$ of the asymptomatic leaf halves and $100 \%$ of the symptomatic leaf halves tested positive for the virus. In a phloem-unloading study in leaves of Nicotiana benthamiana, Potato virus $X$ was found to unload from the phloem into the sink regions throughout both leaf halves of intact leaves (Roberts et al. 1997). Assuming similar systemic unloading patterns for other plant viruses, a likely explanation for our findings is that BNRBV does not move systemically, resulting in entire leaves on shoots or leaf halves remaining virus-free. This would suggest that asymptomatic tissue testing positive for BNRBV results from the virus being identified by RT-PCR early after infection but before disease symptoms start developing. In the case of the cuttings taken for vegetative propagation, care was taken to obtain only cuttings free of symptoms that were distal to symptomatic tissue.

The introduction of virus-free tissue culture-derived trap plants into BNRBV-affected plantings resulted in symptom development with a delay of approximately 2 to 3 weeks relative to the detection of symptoms on field plants. Because trap plants were placed in the field approximately 3 months prior to symptom development in field plants, the 2- to 3-week delay of symptom development on the trap plants raises the possibility that the virus is being transmitted from field plants to trap plants. If eriophyid mites vector BNRBV, as suggested by Burkle et al. (2012), the overwintering of the mites on field plants could explain a 2- to 3-week lag between the appearance of symptoms on field plants compared with trap plants. Indeed, adult female eriophyid mites can overwinter in buds and start feeding on new growth when buds break in the spring (Burrack 2015; Davis and Beddes 2011). Interestingly, BNRBV spread within greenhouses occurred in the presence of large populations of eriophyid mites of the genus Calacarus (Cantu-Iris et al. 2013). The results do not preclude the possibility that the potential vector is moving into the field from an alternate host, and further studies are needed to identify the vector and understand the transmission aspects of the disease etiology.
In conclusion, the results from these studies provide preliminary insights into important aspects of BNRBV epidemiology. This work lays the foundation for future research to better understand how BNRBV moves within infected plants, to determine whether the virus induces RNA silencing, and to identify the vector and the spatiotemporal dynamics of the disease to better understand its epidemiology.

\section{Acknowledgments}

This work was supported by the Georgia Agricultural Commodity Commission for Blueberries, the Southern Region Small Fruit Consortium, and the United States Department of Agriculture National Institute for Food and Agriculture Specialty Crop Research Initiative (grant number 2008-51180-19579). We thank B. Shirley for help with the trap plant study; C. Laster and M. Seader for greenhouse support; and extension agents E. Andrews, T. Flanders, J. Jacobs, J. E. Smith, and D. Stanaland for cooperation during field site selection and communication with producers.

\section{Literature Cited}

Burkle, C., Olmstead, J. W., and Harmon, P. F. 2012. A potential vector of Blueberry necrotic ring blotch virus and symptoms on various host genotypes. (Abstr.) Phytopathology 102:S4.17.

Burrack, H. 2015. Blueberry bud mite. Pages 26-27 in: 2015 Southeastern Regional Blueberry Integrated Management Guide, Spec. Bull. 48. P. M. Brannen and P. Smith, eds. University of Georgia Cooperative Extension Service, Athens.

Cantu-Iris, M., Harmon, P.F., Londoño, A., and Polston, J.E. 2013. A variant of Blueberry necrotic ring blotch virus associated with red lesions in blueberry. Arch. Virol. 158:2197-2200.

Chung, K. R. and Brlanksy, R. H. 2006. Citrus diseases exotic to Florida: Citrus leprosis. Fact Sheet PP-226. Department of Plant Pathology, University of Florida Cooperative Extension Service, Gainesville.

Davis, R., and Beddes, T. 2011. Eriophyid mites (bud, blister, gall, and rust mites). Utah Pests Fact Sheet ENT-149-11. Utah State University Cooperative Extension and Utah Pest Diagnostic Laboratory, Logan.

Martin, R.R., Polashock, J. and Tzanetakis, I.E. 2012. New and emerging viruses of blueberry and cranberry. Viruses 4:2831-2852.

Polashock, J. J., Ehlenfeldt, M. K., and Crouch, J. A. 2009. Molecular detection and discrimination of Blueberry red ringspot virus strains causing disease in cultivated blueberry and cranberry. Plant Dis. 93:727-733.

Quito-Avila, D., Brannen, P.M., Cline, W.O., Harmon, P.F., and Martin, R.R. 2013. Genetic characterization of Blueberry necrotic ring blotch virus, a novel RNA virus with unique genetic features. J. Gen. Virol. 94:1426-1434.

Roberts, A. G., Santa Cruz, S., Roberts, I. M., Prior, D. A. M., Turgeon, R., and Oparka, K. J. 1997. Phloem unloading in sink leaves of Nicotiana benthamiana: Comparison of a fluorescent solute with a fluorescent virus. Plant Cell 9:1381-1396.

Rodrigues, J. C. V., Kitajima, E. W., Childers, C. C., and Chagas, C. M. 2003. Citrus leprosis virus vectored by Brevipalpus phoenicis (Acari: Tenuipalpidae) on citrus in Brazil. Exp. Appl. Acarol. 30:161-179.

Scherm, H., Brannen, P. M., and Cline, W.O. 2008. Blueberry red ringspot virus: Prevalence in Georgia and North Carolina, and yield losses associated with the disease. Final Report 2008-04. Southern Region Small Fruit Consortium, North Carolina State University, Raleigh.

Wolfe, K., and Stubbs, K. 2014. 2013 Georgia Farm Gate Value Report AR14-01. University of Georgia, Center for Agribusiness and Economic Development, Athens. 